\title{
Penerapan Permainan What's In Here Berbasis Model TGT untuk Menumbuhkan Kemampuan Berpikir Kritis Siswa
}

\author{
Novika Hapsari Susilo $^{1 *}$, Arfilia Wijayanti ${ }^{2}$, Filia Prima Artharina ${ }^{3}$
}

1,2,3 Pendidikan Guru Sekolah Dasar, Fakultas Ilmu Pendidikan, Universitas PGRI Semarang

\author{
A R T I C L E I N F O \\ Article history: \\ Received 10 February \\ 2019 \\ Received in revised form \\ 09 March 2019 \\ Accepted 15 Aril 2019 \\ Available online 25 May \\ 2019 \\ Kata Kunci: \\ IPS, Problem Based \\ Learning, Role Pyaing, \\ Motivasi, Hasil Belajar. \\ Keywords: \\ Social Science, Problem \\ Based Learning, Rolle \\ Pyaing, the motivation, the \\ results of the study.
}

\begin{abstract}
A B S T R A K
Penelitian ini bertujuan untuk mengetahui penerapan permainan What's In Here berbasis model Team Games Tournament untuk menumbuhkan kemampuan berpikir kritis siswa kelas IV di SDN Gabus 04 Pati. Penelitian ini merupakan penelitian kuantitatif. Penelitian ini menggunakan One Group Pretest-Posttest Design. Populasi dalam penelitian ini adalah semua peserta didik kelas IV di SDN Gabus 04 Pati berjumlah 31 siswa tahun ajaran 2018/2019. Intrumen yang digunakan adalah (1) Tes. (2) Angket, (3) Observasi, dan (3) Dokumentasi. Analisis data menggunakan teknis analisis data uji normalitas, uji hipotesis (uji-t), dan Uji N-Gain. Uji normalitas digunakan untuk mengetahui kelas tersebut berdistribusi normal atau tidak. Uji hipotesis menggunakan uji t-test. Uji N-Gain digunakan untuk menghitung kemampuan berpikir kritis siswa. Hasil penelitian yang dilakukan dapat disimpulkan bahwa permainan What's In Here dapat diterapkan untuk menumbuhkan kemampuan berpikir kritis siswa kelas IV di SDN Gabus 04 Pati. Hal ini dapat dilihat dari peningkatan kemampuan berpikir kritis siswa. Selain itu diperkuat dengan hasil perhitungan uji $t$ diperoleh thitung untuk kemampuan berpikir kritis sebesar 7,232 dan ttabel sebesar 1,694 karena thitung $(7,232)>$ ttabel $(1,694)$ maka hal ini menunjukkan bahwa uji t kemampuan berpikir kritis signifikan. Sedangkan hasil observasi yang dilakukan aspek paling tinggi yaitu pada keterampilan mensintesis sebesar $78,2 \%$.
\end{abstract}

\section{A B S T R A C T}

This study aims to determine the application of What 's In Here game based on the Team Games Tournament (TGT) model to foster critical thinking skills of fourth grade students at Gabus 04 SDN Pati. This research is quantitative research. This study uses One Group Pretest-Posttest Design. The population in this study were all fourth grade students at Gabus 04 Pati SDN totaling 31 students in the 2018/2019 school year. The instruments used are (1) Test. (2) Questionnaire, (3) Observation, and (3) Documentation. Data analysis using technical analysis of normality test data, hypothesis testing (t-test), and N-Gain Test. The normality test is used to find out whether the class is normally distributed or not. Hypothesis testing uses the $\mathrm{t}$-test. The N-Gain test is used to calculate students' critical thinking abilities. The results of the research conducted can be concluded that the game What 's In Here can be applied to foster critical thinking skills of fourth grade students at Gabus SDN 04 Pati. This can be seen from the improvement of students' critical thinking skills. Besides that it is reinforced by the results of t-test calculations obtained by tcount for critical thinking skills of 7.232 and ttable of 1.694 because of tcount (7.232)> ttable (1.694), so this shows that the test of critical thinking skills is significant. While the results of the observations carried out the highest aspects, namely the synthesizing skills of $78.2 \%$. 


\section{Pendahuluan}

Dalam kehidupan sehari-hari manusia tidak akan lepas dengan pendidikan, pendidikan sangat berperan penting bagi kehidupan sehari-hari khususnya untuk membentuk manusia dari sejak usia dini sampai dewasa dan sebagai penerus bangsa yang lebih berkembang, maju dan berkualitas tinggi di jenjang pendiidkan. Pendidikan adalah usaha yang dilakukan secara sadar dan terencana untuk mewujudkan suasana belajar dan proses pembelajaran agar peserta didik dapat mengembangkan potensi dirinya sehingga memiliki kekuatan spiritual, keagamaan, sikap, pengetahuan serta ketrampilan yang diperlukan dirinya di masa masa mendatang (Ardiansah,2018). Pendidikan memiliki peranan penting dalam kehidupan untuk meningkatkan dan mengembangkan kualitas sumber daya manusia (SDM) dalam menghadapi perubahan pada masa yang akan datang. Keadaan tersebut disesuaikan dengan BSNP (2010), tentang Pengembangan Paradigma Pendidikan Nasional abad 21 menyatakan bahwa Pendidikan ilmu pengetahuan bukan hanya membuat seseorang peserta didik berpengetahuan, melainkan juga menganut sikap keilmuan dan terhadap ilmu pengetahuan, yaitu kritis, logis, inventif dan inovatif, serta konsisten, namun disertai pula dengan kemampuan beradaptasi. Disamping memberikan ilmu pengetahuan, Pendidikan hendaklah disertai penanaman nilai-nilai luhur dan sikap terpuji untuk dapat membekali peserta didik dalam bermasyarakat .pembelajaran. Implementasi kurikulum memiliki posisi yang sangat menentukan bagi keberhasilan kurikulum sebagai rencana tertulis (Said Hamid, 2010).

Pembelajaran pada abad 21 dalam implementasi kurikulum 2013 dilaksanakan melalui model pembelajaran yang menekankan peserta didik untuk dapat mencari tahu dari berbagai sumber observasi, hal ini dimaksudkan agar peserta didik memiliki kemampuan merumuskan masalah. Pembelajaran abad 21 menitik beratkan pada kemampuan berpikir kritis bukan hanya berpikir mekanistis. Dengan demikian dukungan dari kerjasama dan kolaborasi juga ditekankan dalam menyelesaikan masalah-masalah dalam proses pembelajaran (Husamah dan Setyaningrum, 2013). Untuk mencapai tujuan tersebut, diperoleh adanya kreativitas guru dalam mengelola dan melaksanakan pembelajaran yang berbasis pada pengalaman belajar dan pemecahan masalah.

Kurikulum 2013 merupakan suatu kebijakan pemerintah dalam bidang pendidikan, yang diharapkan dapat memberikan keseimbangan aspek kognitif, aspek afektif, dan aspek psikomotor secara berimbang. Dengan demikian, melalui implementasi kurikulum 2013 pendidikan diharapkan dapat melaksanakan sarana yang tepat untuk menumbuhkan kreativitas dan berpikir kritis peserta didik. Dalam rangka mewujudkan hal tersebut, maka diperlukan pelaksanaan kurikulum di sekolah lebih memperhatikan proses mengamati, menanya, menalar, dan mencoba dalam pembelajaran. Kurikulum 2013 tidak hanya menuntut guru dalam perubahan konsep, metode, komitmen, dan strategi pendekatan, tetapi juga mencanangkan pembelajaran berbasis teks. Oleh karena itu, siswa dituntut mampu memproduksi sebuah teks (Kusuma , 2018). Implementasi pendekatan Saintifik adalah proses pembelajaran yang disarankan dalam Kurikulum 2013. Pendekatan Saintifik dirancang sedemikian rupa agar peserta didik secara aktif mampu mengonstruksi konsep, hukum atau prinsip pengetahuan melalui tahapan-tahapan mengamati (untuk mengidentifikasi atau menemukan masalah), merumuskan masalah, mengajukan atau merumuskan hipotesis, mengumpulkan data dengan berbagai teknik, menganalisis data, menarik kesimpulan dan mengomunikasikan konsep (Yuna, 2016) .

Pada hakekatnya kurikulum adalah seperangkat rencana dan pengaturan mengenai tujuan, isi dan bahan pelajaran serta cara yang digunakan sebagai pedoman penyelenggaraan kegiatan pembelajaran untuk mencapai tujuan pendidikan tertentu (UU Sisdiknas). Berangkat dari definisi kurikulum berdasarkan UU Sisdiknas tersebut, setidaknya ada tiga komponen penting yang ada dalam kurikulum yaitu komponen tujuan pendidikan, komponen proses, dan komponen evaluasi (Suyatmini, 2010).

Pembelajaran Sains di sekolah memiliki karakteristik analisis, lengkap, cermat, dan menghubungkan antara suatu peristiwa lain. Sehingga keseluruhan membentuk suatu perspektif yang baru tentang objek yang diamatinya. Dengan demikian pelaksanaan pembelajaran Sains (Ilmu Pengetahuan Alam) hendaklah didasarkan pada percobaan pengamatan yang dilakukan oleh peserta didik sebagai implementasi kurikulum 2013. Pembelajaran akan lebih optimal apabila guru mampu memvariasi model saintifik dengan permainan. (Feasey ,2009), Terdapat tujuh kegiatan permainan menyenangkan yang dapat digunakan guru untuk mengembangkan keterampilan belajar sains peserta didik usia 5-11 tahun. Kegiatan perminan tersebut adalah jumpstaring science questioning, science vocabulary, science observation, science analysis, researching science information, science communication, and science revision. Jika dilihat dari macam-macam permainan yang dikemukakan oleh Rosemary Feasey, kesemuanya termasuk keterampilan proses belajar sains, contohnya science questioning yaitu keterampilan bertanya. 
Hasil observasi pada tanggal 2 Juni 2018 di SD Negeri Gabus 04 Pati, observasi dilakukan dengan mengamati langsung kegiatan pembelajaran dan melalui wawancara dengan guru kelas IV yaitu Bapak Imam Santoso. Hasil wawancara peneliti dengan guru kelas IV ada beberapa permasalahan yang dihadapi, beliau mengatakan bahwa hasil belajar siswa rendah pada mata pelajaran Ilmu Pengetahuan Alam (IPA). Berdasarkan data nilai Ulangan Tengah Semester Ganjil, dari 31 siswa terdapat 11 siswa yang mencapai KKM, sedangkan 20 siswa masih dibawah KKM dengan rata-rata keseluruhan 59,7. Kriteria Ketuntasan Minimal (KKM) untuk mata pelajaran IPA yaitu 75. Hal tersebut disebabkan oleh siswa merasa jenuh dan tidak fokus, siswa merasa malu dan takut salah untuk mengajukan pertanyaan atau mengutarakan pendapatnya kepada guru.

Bapak Imam Santoso menjelaskan bahwa permasalahan yang muncul dalam SD Negeri Gabus 04 dikarenakan siswa belum terbiasa untuk berpikir kritis, merumuskan masalah, dan menyelesaikan masalah. Ketika diberi pertanyaan, siswa mampu memberi jawaban namun tidak dapat menjelaskan alasan atau pendapat yang berkaitan dengan jawabannya. Ketika diminta untuk berpendapat maupun mengajukan pertanyaan, siswa juga pasif. Dalam hal ini kemampuan berpikir kritis siswa rendah hanya $25 \%$ siswa mampu berpikir kritis sedangkan $75 \%$ siswa merasa malu dan takut untuk mengajukan atau mengutarakan pendapatnya. Guru juga belum menggunakan permainan berbasis model dalam proses pembelajaran. Dilihat dalam proses pembelajaran guru hanya menggunakan buku serta LKS. Dengan demikian kemampuan berpikir kritis dapat meningkat sejalan dengan pendapat Syah (2010), "berpikir kritis adalah perwujudan perilaku belajar terutama yang berkaitan dengan pemecahan masalah. Pada umumnya siswa yang berpikir kritis akan menggunakan prinsip-prinsip dan dasar-dasar pengertian di dalam menjawab pertanyaan". Dalam pemecahan masalah, kemampuan berpikir kritis juga diperlukan karena dapat merumuskan, memformulasikan dan menyelesaiakan masalah. Dengan demikian diperlukan model pembelajaran yang mampu meningkatkan berpikir kritis, merumuskan masalah, dan menyelesaikan masalah yaitu Team Games Tournament. Hal itu dapat dibuktikan dengan hasil pengamatan di dalam kelas sebagai berikut:

Tabel 1. Data Awal

\begin{tabular}{lllll}
\hline No. & Kriteria Ketuntasan Minimal & Jumlah & Presentasi & Keterangan \\
\hline 1. & $\leq 75$ & 8 & $75 \%$ & Tidak Tuntas \\
2. & $\geq 75$ & 23 & $25 \%$ & Tuntas \\
\hline
\end{tabular}

Beberapa hasil penelitian yang berkaitan dengan permainan What's In Here adalah penelitian yang dilaksanakan oleh Selly Nurina Suraya pada tahun 2014 dengan judul "Permainan What's In Here? sebagai Alternatif Metode Pembelajaran untuk Melatih Keterampilan Bertanya Siswa Sekolah Dasar". Melalui permainan, kegiatan pembelajaran dirancang guru agar siswa dapat mengembangkan keterampilan observasi, melatih keterampilan berbahasa, mengembangkan daya ingat, menerapkan pengetahuan yang didapat, serta berlatih mengembangkan ide-ide baru.

Sedangkan penelitian yang dilakukan oleh Ni Md. Rusnadi, dkk pada tahun 2013 dengan judul penelitian "Penerapan Model Pembelajaran Kooperatif Tipe Team Games Tournament untuk Meningkatkan Kemampuan Berpikir Kritis dan Hasil Belajar IPA". Hasil penelitian menunjukkan bahwa penggunaan model pembelajaran berpengaruh untuk meningkatkan kemampuan berpikir kritis siswa Sekolah Dasar.

Permainan berbasis model pembelajaran yang sesuai dapat membantu siswa dalam meningkatkan kemampuan berpikir kritis. (Slavin ,2009), Model pembelajaran Team Games Tournament dipilih karena melibatkan peran siswa sebagai tutor sebaya, mengandung unsur permainan dan penguatan yang memungkinkan peserta didik dapat belajar lebih rileks selain menumbuhkan tanggung jawab, kejujuran, kerja sama, persaingan sehat serta keterlibatan belajar. Aktifitas belajar dengan permainan What's In Here berbasis model Team Games Tournament diharapkan dapat membantu peserta didik lebih aktif dalam pembelajaran dan mampu mengemukakan pendapat dengan baik. Maka peneliti merencanakan untuk menggunakan permainan What's In Here berbasis model Team Games Tournament untuk meningkatkan kemampuan berpikir kritis siswa. Karena permainan tersebut sangat menarik untuk menumbuhkan partisipasi siswa dalam kegiatan pembelajaran yang dapat menumbuhkan kemampuan berpikir kritis. Permainan What's In Here berbasis Model Team Games Tournament dapat mendorong siswa untuk ikut aktif dalam belajar IPA. Pada Tema 5 "Pahlawanku" dalam sub tema 3 "Sikap Kepahlawanan" siswa dapat mengetahui sifat-sifat cahaya berdasarkan berbagai macam cermin seperti cermin cekung, cermin cembung, dan cermin datar (pembelajaran 1) serta periskop (pembelajaran 3). 
Model pembelajaran kooperatif tipe Teams Games Tournament (TGT) salah satu tipe atau model pembelajaran kooperatif yang mudah diterapkan, melibatkan aktivitas seluruh siswa tanpa harus ada perbedaan status, melibatkan peran siswa sebagai tutor sebaya dan mengandung unsur permainan dan penguatan. Keunggulan pembelajaran tipe TGT adalah adanya turnamen akademik dalam proses pembelajaran. Dimana setiap anggota kelompok mewakili kelompoknya untuk melakukan turnamen (Sumardi, 2014). Menurut Roji'ah (2014) dalam proses pembelajaran TGT semua siswa memperoleh tugas, sehingga ada interaksi langsung antara siswa dengan guru dan antara siswa dengan siswa yang bisa melatih siswa untuk berbicara di depan kelas dan dapat meningkatkan hasil belajar siswa. Menurut Soleh (2017) penerapan model pembelajaran kooperatif tipe TGT mewujudkan siswa berperan aktif dan dapat belajar lebih tenang selain dapat memunculkan rasa tanggung jawab, kerjasama, persaingan antar tim secara sehat, dan ketertiban belajar, sehingga diharapkan dapat mengubah hasil belajar siswa ke arah yang lebih baik lagi. Model ini mempunyai beberapa tahapan yakni tahap pengajaran, tahap belajar kelompok, tahap game, tahap turnamen, dan rekognisi team. Model ini dapat dikatakan sesuai karena pada tahap yang dilaksanakan mengandung permainan akademik serta dapat memacu siswa ikut terlibat secara aktif di dalam kegiatan pembelajaran. Menurut Solihah (2016) dengan model pembelajaran TGT siswa yang pintar diusahakan dapat membantu siswa yang kurang, sedangkan bagi siswa yang relatif sudah menguasai materi diharapkan akan lebih memahami materi yang diajarkan. Dengan demikian, kegiatan belajar tidak hanya untuk siswa yang berkemampuan tinggi saja tetapi juga milik siswa yang berkemampuan rata-rata dan rendah. Keterlibatan siswa secara aktif dalam proses belajar mengajar tentu saja dapat menciptakan kondisi belajar menjadi lebih menyenangkan.

Penerapan permaianan merupakan kegiatan paling penting pada pelaksanaan model pembelajaran kooperatif tipe TGT. Siswa akan dibagi pada kelompok kecil yang anggotanya telah dikondisikan oleh guru agar menjadi kelompok heterogen. Pada tahap ini siswa mempelajari materi dan mengerjakan tugas yang diberikan dalam lembar kerja secara berkelompok. Setiap kelompok dalam kegiatan ini melakukan diskusi untuk memecahkan masalah serta saling membantu dalam memahami materi yang sedang dipelajari (Ega , 2014).

Berdasarkan latar belakang di atas penulis tertarik untuk melakukan penelitian dengan judul "Penerapan Permainan What's In Here Berbasis Model Team Games Tournament Untuk Menumbuhkan Kemampuan Berpikir Kritis Siswa Kelas IV SD Negeri Gabus 04".

Berdasarkan latar belakang masalah, maka dapat diidentifikasi sebagai berikut: 1) Siswa merasa jenuh dan tidak fokus, 2) Siswa merasa malu dan takut salah untuk mengajukan pertanyaan atau mengutarakan pendapat kepada guru, 3) Hasil belajar siswa rendah pada mata pelajaran IPA karena belum mencapai nilai KKM 75, 4) Guru belum menggunakan permainan berbasis model pembelajaran yang menarik dalam pembelajaran.

Berdasarkan latar belakang dan identifikasi masalah diatas maka yang dibatasi dalam penelitian ini adalah : 1) Penelitian terbatas pada permainan What's In Here berbasis model Team Games Tournament, 2) Sasaran penelitian terbatas pada kemampuan berpikir kritis siswa.

Berdasarkan Identifikasi masalah dan pembatasan masalah di atas, maka dapat dirumuskan masalah sebagai berikut: Bagaimana penerapan permainan What's In Here berbasis model Team Games Tournament untuk menumbuhkan kemampuan berpikir kritis siswa kelas IV SD Negeri Gabus 04 ? Berdasarkan rumussan masalah, diperoleh tujuan penelitian sebagai berikut : Untuk mengetahui penerapan permainan What's In Here berbasis model Team Games Tournament untuk menumbuhkan kemampuan berpikir kritis siswa kelas IV SD Negeri Gabus 04.

\section{Metode}

Penelitian ini merupakan penelitian kuantitatif. Penelitian ini menggunakan One Group PretestPosttest Design. Penelitian dilaksanakan di SD Negeri Gabus 04 Pati pada tanggal 11, 12, dan 13 Desember 2018 pada tahun ajaran 2018/2019 semester ganjil pada siswa kelas IV SD Negeri Gabus 04 Pati Tahun pelajaran 2018/2019.

Populasi dalam penelitian ini adalah seluruh peserta didik kelas IV SD Negeri Gabus 04 Pati berjumlah 31 siswa tahun ajaran 2018/2019. Dengan demikian hasil perlakuan dapat diketahui lebih akurat, karena dapat membandingkan dengan keadaan yang sebelum dan setelah diberi perlakuan. Desain ini dapat digambarkan sebagai berikut: 


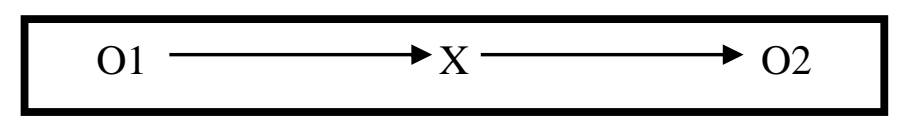

Gambar 1. One Group Pretest - Posttest Design

Keterangan :

$\begin{array}{ll}01 & \text { : nilai pretest } \\ \mathrm{O} 2 & \text { : nilai posttest } \\ \mathrm{X} & \text { : perlakuan }\end{array}$

Teknik pengumpulan data dalam penelitian ini adalah wawancara, dokumentasi, observasi, dan tes bertujuan untuk mendapatkan informasi tentang kondisi awal siswa serta materi yang akan diajarkan.

Dokumentasi dalam penelitian ini digunakan untuk mendapatkan dokumen sekolah mengenai nama siswa, jumlah siswa, dan data-data yang diperlukan dalam penelitian. Metode dokumentasi digunakan untuk daftar nilai, daftar nama siswa dan dokumen pelaksanaan kegiatan pembelajaran selama penelitian.

Observasi digunakan untuk mengetahui seberapa tingkat kemampuan berpikir kritis siswa dengan pengamatan secara langsung selama proses pembelajaran.

Teknik tes digunakan untuk menilai kemampuan siswa yang mencakup pengetahuan dan kemampuan berpikir kritis yang dimiliki siswa. Penulis melakukan tes untuk mengetahui kemampuan berpikir kritis siswa dengan memberikan soal kepada siswa. Instrumen soal yang diberikan kepada siswa telah divalidasi oleh dosen ahli. Soal yang diberikan adalah soal uaraian.

Penganalisaan hasil yaitu menganalisa item soal yang diuji cobakan melalui validasi inst rumen. Setelah melakukan validasi instrumen kemudian dilanjutkan melakukan penelitian di kelas IV SD Negeri Gabus 04 Pati.

Teknik analisis dalam penelitian ini ada beberapa tahapan, yaitu tahap awal yang merupakan tahap pemadaman sampel dan tahap akhir yang merupakan tahap analisis data untuk menguji hipotesis penelitian.

1. Uji Normalitas Awal (Pretest)

Uji normalitas dilakukan untuk mengetahui populasi berdistribusi normal atau tidak. Hipotesis sebagai berikut:

H0 : data berdistribusi normal

H1 : data tidak berdistribusi normal

Sudjana (2005: 466-467) uji kehormatan dilakukan secara parametrik dengan menggunakan penaksir rata-rata dan simpangan baku, maka dalam bagian ini akan diperhatikan uji kenormalan secara non parametrik. Uji yang digunakan dikenal dengan uji Liliefors. Misal sampel acak dengan hasil pengamatan $\mathrm{x} 1, \mathrm{x} 2, . . \mathrm{x} \alpha$. Sampel uji hipotesis nol bahwa sampel berasal dari populasi berdistribusi normal melawan hipotesis tandingan bahwa berdistribusi tidak normal.

2. Uji Normalitas Akhir (Posttest)

Langkah-langkah pengujian normalitas sama dengan langkah-langkah uji normalitas pada analisis data awal. Menurut Sudjana (2005: 466-467) uji kenormalan dilakukan secara parametrik dengan menggunakan penaksir rata-rata dan simpangan baku, maka dalam bagian ini akan diperhatikan uji kenormalan secara nonparametrik. Uji yang digunakan dikenal dengan uji Liliefors. Misal sampel acak dengan hasil pengamatan $\mathrm{x} 1, \mathrm{x} 2, \ldots \mathrm{zn}$, sampel uji hipotesis nol bahwa sampel berasal dari populasi berdistribusi normal melawan hipotesis tandingan bahwa berdistribusi tidak normal.

3. Uji T-test

Cara mengetahui adakah perbedaan kemampuan berpikir kritis siswa, maka digunakan Uji-t adapun rumus yang digunakan yaitu:

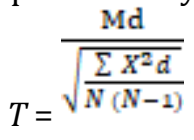

Keterangan:

Md : Mean dari deviasi (d) antara Pretest dan Posttest

$\sum$ : Jumlah kuadrat deviasi

Xd : Deviasi masing-masing subjek (d-Md) 
$\mathrm{N}$ : Banyaknya subjek pada sampel

$\mathrm{db}$ : Ditentukan dengan (N-1)

Uji $t$-test digunakan untuk mengetahui perbedaan antara kemampuan berpikir kritis siswa sebelum diberi perlakuan dan sesudah diberi perlakuan.

4. Kemampuan Berpikir Kritis (N-Gain)

$$
N-\text { Gain }=\frac{\text { Skor Posttest }- \text { Skor Pretest }}{\text { Skor Maks }- \text { Skor Pretest }} \times 100
$$

Tabel 2. Hasil skor Gain Ternormalisasi

\begin{tabular}{lc}
\hline \multicolumn{1}{c}{ Persentase } & Klasifikasi \\
\hline $\mathrm{N}-$ Gain $>70$ & Tinggi \\
$30 \leq \mathrm{N}-$ Gain $\leq 70$ & Sedang \\
$\mathrm{N}-$ Gain $<30$ & Rendah \\
\hline
\end{tabular}

\section{Hasil dan Pembahasan}

Hasil penelitian yang telah dilaksanakan yaitu "Penerapan Permainan What's In Here Berbasis Model Team Games Tournament untuk Menumbuhkan Kemampuan Berpikir Kritis Siswa". Penelitian ini dilaksanakan pada tanggal 11, 12, 13 Desember 2018. Pada Kriteria Ketuntasan Minimal (KKM) 75. Dalam penelitian ini menggunakan satu kelas dengan jumlah 31 siswa. Penelitian ini merupakan penelitian kuantitatif yang menggunakan validasi uji instrumen. Penelitian ini menggunakan desain dengan jenis One Group Pretest Posttest Design. Dalam design ini terdapat pretest sebelum diberi perlakuan untuk mengetahui keadaan awal dan posttest untuk mengetahui penerapan Permainan What's In Here Berbasis Model TGT untuk Menumbuhkan Kemampuan Berpikir Kritis Siswa.

Penelitian ini merupakan penelitian untuk mengetahui penerapan Permainan What's In Here Berbasis Model TGT untuk Menumbuhkan Kemampuan Berpikir Kritis Siswa pada siswa kelas IV. Penelitian ini diawali dengan membuat soal sesuai dengan materi yang telah ditentukan.

1) Deskripsi Kemampuan Kognitif

Data hasil penelitian diperoleh dari nilai pretest dan posttest kemampuan kognitif siswa. Nilai pretest dan posttest dinyatakan tuntas jika memenuhi KKM (75). Adapun Kriteria Ketuntasan Minimal (KKM) SD Negeri Gabus 04 yaitu 75. Perhitungan nilai pretest dan nilai posttest setelah diberikan perlakuan hasilnya berbeda. Berikut tabel nilai pretest dan posttest siswa kelas IV SD Negeri Gabus 04.

Data hasil belajar nilai prestest dan posttest siswa kelas IV SD Negeri Gabus 04 tahun ajaran 2018/2019 dapat dilihat pada tabel berikut:

Tabel 3. Data Hasil Pretest dan Posttest

\begin{tabular}{lll}
\hline Keterangan & Pretest & Posttest \\
\hline Nilai tertinggi & 93 & 99 \\
Nilai terendah & 32 & 55 \\
Rata-rata & 61.967 & 81.806 \\
Siswa tuntas & 10 & 24 \\
\hline
\end{tabular}

Sumber : Data Hasil Penelitian 2018

\section{Hasil Pretest dan Posttest}

terdapat perbedaan antara nilai terendah, nilai tertinggi, nilai rata-rata kelas dan jumlah siswa yang tuntas pada saat pretest dan posttest. Nilai pretest diperoleh nilai terendah 32 dan nilai tertinggi 93 sedangkan nilai posttest diperoleh nilai terendah 55 dan nilai tertinggi 99. Nilai rata-rata pretest atau sebelum diberi perlakuan sebesar 61,967 setelah diberikan perlakuan dengan menggunakan permainan What's In Here berbasis model Team Games Tournament nilai rata-rata posttest siswa yaitu 81,806. 


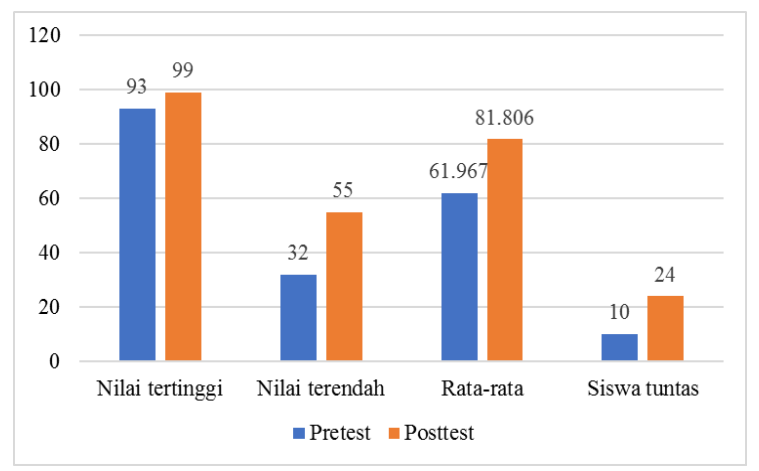

Gambar 2. Diagram Hasil Pretest dan Posttest

Berdasarkan gambar 2 menunjukkan bahwa terdapat peningkatan antara pretest yang sebelum diberikan perlakuan dengan nilai posttest yang sudah diberikan perlakuan dengan menggunakan permainan What's In Here berbasis model Team Games Tournament.

Hasil nilai pada penelitian ini yang dijadikan sebagai data akhir penelitian yaitu nilai posttest. Data yang diperoleh kemudian digunakan uji normalitas dan uji t untuk menguji hipotesis penelitian ada atau tidak ada perbedaan hasil belajar yang signifikan antara pretest dan posttest.

\section{1) Kemampuan Berpikir Kritis}

Kemampuan berpikir siswa dilihat dari observasi selama proses pembelajaran dengan menggunakan 5 aspek yaitu; (1) keterampilan menganalisis, (2) keterampilan mensintesis, (3) keterampilan mengenal dan memecahkan masalah, (4) keterampilan menyimpulkan, serta (5) keterampilan mengevaluasi atau menilai. Dari aspek tersebut, terlihat kemampuan berpikir kritis siswa dengan klasifikasi tinggi, sedang, dan rendah. Dapat terlihat kemampuan berpikir kritis sesuai klasifikasi $\mathrm{N}-G a i n$. Berikut tabel kemampuan berpikir kritis siswa:

Tabel 4. Kemampuan Berpikir Kritis Siswa

\begin{tabular}{lcc}
\hline Klasifikasi & Jumlah Siswa & Persentase \\
\hline Tinggi & 22 & $71 \%$ \\
Sedang & 9 & $29 \%$ \\
Rendah & - & - \\
\hline
\end{tabular}

Berdasarkan Tabel 4 dapat dilihat pada kelas IV dari 31 siswa mempunyai kemampuan berpikir kritis yaitu 22 siswa mempunyai kemampuan berpikir kritis tinggi sedangkan 9 siswa memiliki kemampuan berpikir kritis sedang. Melalui klasifikasi N-Gain dengan permainan What's In Here maka kemampuan berpikir kritis siswa setelah diberi perlakuan memiliki $71 \%$ tinggi serta $29 \%$ sedang dengan menggunakan perhitungan N-Gain.

Berdasarkan data pada tabel tersebut, kemudian disajikan dalam bentuk diagram persentase kemampuan berpikir kritis siswa kelas IV SD Negeri Gabus 04 sebagai berikut:

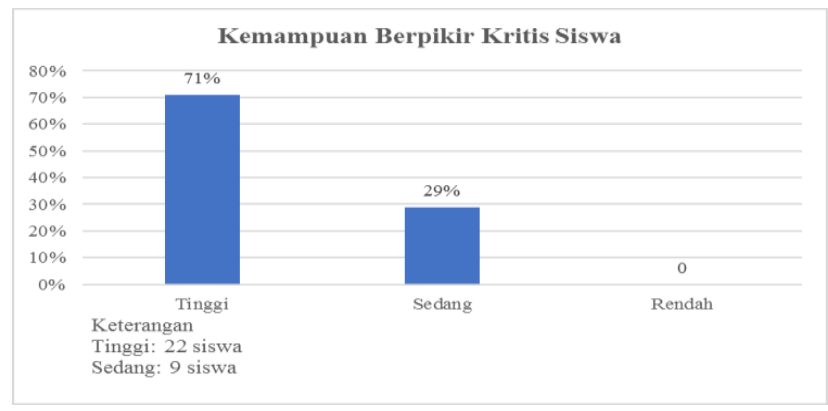

Gambar 3. Diagram Kemampuan Berpikir Kritis Siswa 
Berdasarkan kemampuan berpikir kritis siswa pada gambar 3 merupakan hasil dari obeservasi selama proses pembelajran Dalam proses pembelajaran siswa diberikan permaianan What's In Here berbasis model Team Games Tournament dimana permaianan tersebut dapat berpengaruh dalam pembelajaran dikarenakan siswa senang dalam hal bermain. Kemampuan berpikir kritis juga dipengaruhi beberapa aspek yaitu keterampilan menganalisis, keterampilan mensintesis, keterampilan mengenal dan memecahkan masalah, keterampilan menyimpulkan, serta keterampilan mengevaluasi atau menilai. Data hasil pengamatan aspek dapat kemampuan berpikir kritis siswa dapat dilihat pada Tabel

Tabel 5. Data Hasil Persentase Aspek Kemampuan Berpikir Kritis

\begin{tabular}{|c|c|c|}
\hline Aspek Yang Diamati & Indikator Berfikir Kritis & Persentase \\
\hline 1. Keterampilan & 1.1 Mengidentifikasi masalah & $78,2 \%$ \\
\hline Menganalisis & $\begin{array}{l}\text { 1.2 Menggunakan konsep yang sudah diketahui dalam } \\
\text { suatu permasalahan } \\
\text { 1.3 Menyelesaikan suatu persoalan dengan cepat }\end{array}$ & \\
\hline $\begin{array}{l}\text { 2. Keterampilan } \\
\text { Mensintesis }\end{array}$ & $\begin{array}{l}\text { 2.1 Mencari dan menghubungkan antara masalah yang } \\
\text { didiskusikan dengan masalah lain yang relevan } \\
\text { 2.2 Mengomunikasikan gagasan, perasaan, dan } \\
\text { pengalaman dalam bentuk tulisan }\end{array}$ & $70,3 \%$ \\
\hline $\begin{array}{l}\text { 3. Keterampilan } \\
\text { Mengenal dan } \\
\text { Memecahkan Masalah }\end{array}$ & $\begin{array}{l}\text { 3.1 Memahami masalah } \\
\text { 3.2 Merencanakan / merumuskan penyelesaian masalah } \\
\text { 3.3 Melaksanakan penyelesaian masalah sesuai rencana } \\
\text { 3.4 Melakukan pengecekan kembali terhadap semua } \\
\text { langkah pemecahan masalah }\end{array}$ & $70,9 \%$ \\
\hline $\begin{array}{l}\text { 4. Keterampilan } \\
\text { Menyimpulkan }\end{array}$ & $\begin{array}{l}\text { 4.1 Menyusun dan menyampaikan laporan secara } \\
\text { sistematis dan jelas } \\
\text { 4.2 Menyimpulkan hasil percobaan }\end{array}$ & $70 \%$ \\
\hline $\begin{array}{l}\text { 5. Keterampilan } \\
\text { Mengevaluasi } \\
\text { Menilai } \\
\end{array}$ & $\begin{array}{l}\text { 5.1 Menjawab soal dengan benar } \\
\text { 5.2 Mampu membedakan argumen yang kuat dan relevan } \\
\text { serta argumen yang lemah dan tidak relevan }\end{array}$ & $66,1 \%$ \\
\hline
\end{tabular}

Berdasarkan Tabel 5 terdapat persentase aspek kemampuan berpikir kritis siswa. Persentase aspek kemampuan berpikir kritis siswa diperoleh aspek tertinggi 78,2\% terdapat pada aspek keterampilan menganalisis sedangkan aspek terendah 66,1\% terdapat pada aspek keterampilan mengevaluasi atau menilai. Pada aspek menganalisis indikator paling tinggi terdapat pada indikator mengidentifikasi masalah, siswa diberikan sebuah permainan What's In Here yang sebelumnya belum digunakan siswa tertarik serta penasaran maka indikator mengidentifikasi masalah paling tinggi di aspek keterampilan menganalis.

Persentase aspek kemampuan berpikir kritis siswa setelah diberi perlakuan dengan menggunakan permainan What's In Here berbasis model Team Games Tournament selengkapnya dapat dilihat pada gambar 4 


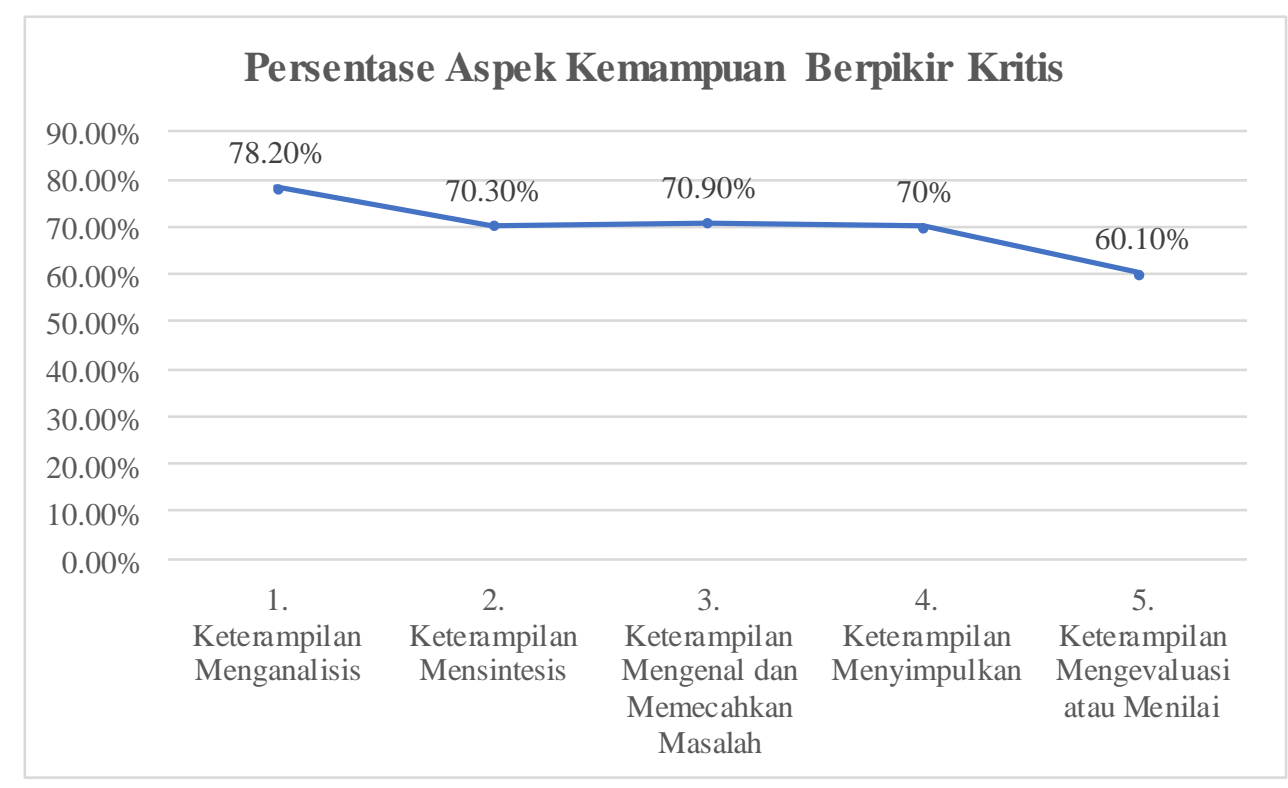

Gambar 4. Diagram Persentase Aspek Kemampuan Berpikir Kritis

Berdasarkan gambar 4 menunjukkan bahwa kemampuan berpikir kritis yang paling tinggi yaitu keterampilan menganalisis sebesar $78,2 \%$.

Penelitian ini sejalan dengan penelitan yang dilakukan oleh Solihah (2016) yang menunjukkan bahwa hasil belajar matematika siswa yang diajarkan dengan model pembelajaran Teams Games Tournament (TGT) lebih tinggi daripada siswa yang diajarkan dengan model pembelajaran Student Teams-Achievement Divisions (STAD).

\section{Simpulan dan Saran}

Berdasarkan hasil penelitian dan pembahasan dalam penelitian ini dapat disimpulkan bahwa permainan What's In Here berbasis model Team Games Tournament dapat diterapkan untuk menumbuhkan kemampuan berpikir kritis siswa kelas IV SD Negeri Gabus 04 semester I tahun ajaran 2018/2019. Hal ini dibuktikan dengan analisis uji $t$ dimana $t_{\text {hitung }}>t_{\text {tabel }}$ atau 7,232>1,694 dengan persentase aspek kognitif siswa 29\% tinggi, 55\% sedang, dan 16\% dinyatakan siswa mempunyai aspek kognitif rendah..

Hasil nilai posttest dapat terlihat bahwa kemampuan kognitif siswa meningkat karena penggunaan permainan What's In Here berbasis model Team Games Tournament.

Sedangkan berdasarkan observasi kemampuan berpikir kritis siswa terdapat 22 atau $71 \%$ siswa mempunyai kemampuan berpikir kritis tinggi serta 9 siswa atau 29\% siswa mempunyai kemampuan berpikir kritis sedang. Pada saat observasi menggunakan 5 aspek kemampuan berpikir kritis yaitu keterampilan menganalisis, keterampilan mensintesis, keterampilan mengenal dan memecahkan masalah, keterampilan menyimpulkan, serta keterampilan mengevaluasi atau menilai. Dari 5 aspek tersebut terlihat kemampuan berpikir kritis yang paling tinggi yaitu keterampilan menganalisis sebesar $78,2 \%$.

Kemampuan berpikir kritis siswa sebelum dan sesudah diberi perlakuan berupa penerapan permainan What's In Here berbasis model Team Games Tournament penelitian ini dapat dikatakan berhasil. Dengan meningkatnya kemampuan berpikir kritis siswa sebelum dan sesudah diberi perlakuan berupa penerapan permainan What's In Here berbasis model Team Games Tournament. Permainan What's In Here berbasis model Team Games Tournament memberikan pengaruh yang positif pada siswa sehingga guru dapat menerapkannya sebagai salah satu alternatif cara dalam pembelajaran yang dapat meningkatkan kemampuan berpikir kritis siswa.

\section{Daftar Rujukan}

Archambault, J. 2008. "The Effects of Developing Kinematics Concepts Graphically Prior to Introducing Algebraic Problem Solving Techniques". Action Research required for the Master of Natural Science degree with concentration in physics. Arizona State University. 
Ardiansah, Fandi Eka, dan Setiyo Hartoto. 2018. Pengaruh Model Pembelajaran Kooperatif Tipe Teams Games Tournament (TGT) terhadap Motivasi Belajar Renang Gaya Bebas (Studi Pada Siswa Kelas XI SMA Negeri 1 Wonoayu - Sidoarjo). Jurnal Pendidikan Olahraga dan Kesehatan Vol. 06 No. 01 Hal. 55-59.

Ega , 2104. Model pembelajaran Teams Games Tournament untuk meningkatkan hasil belajar siswa SMK: Universitas Pendidikan Indonesia.

Feasey, Rosemary. 2009. Jumpstart! Science. Games and Activities for Ages 5-11. A David Fulton Book. London and New York: Routledge.

Husamah \& Setyaningrum, Y. 2013. Desain Pembelajaran Berbasis Pencapaian Kompetensi: Panduan Merancang Pembelajaran untuk Mendukung Implementasi Kurikulum 2013. Jakarta: Prestasi Pustakaraya.

Hasan, Said Hamid. 2000. "Pengembangan kurikulum berbasis masyarakat". Makalah seminar nasional pengembangan program pendidikan berbasis kewilayahan menyongsong diterapkannya otonomi daerah: UPI Bandung.

Kusuma, H. 2018. pembelajaran menulis teks cerita dongeng berbasis kearifan lokal pada siswa kelas iv, Jurnal Pendidikan Edutama.

Ni Md Rusnadi, dkk. 2013. Penerapan Model Pembelajaran Kooperatif Tipe Team Games Tournament untuk Meningkatkan Kemampuan Berpikir Kritis dan hasil Belajar IPA: Mimbar PGSD UNDIKSHA.

Roji'ah, Hera Deswita, dan Arcat. 2014. Pengaruh Model Pembelajaran Team Games Tournament (TGT) terhadap Hasil Belajar Matematika Siswa Kelas VIII MTs Thamrin Yahya Rambah Hilir pada Materi Operasi Aljabar. E-Journal Mahasiswa Prodi Matematika vol 1 No. 1.

Selly Nurina S. 2014. Permainan What's In Here? sebagai Alternatif Metode Pembelajaran untuk Melatihkan Keterampilan Bertanya Siswa Sekolah Dasar: Jurnal Pendidikan Dasar dan Pembelajaran. 4(2): 183-190.

Suyatmini. 2010. Implementasi kurikulum 2013 pada pelaksanaan pembelajaran akuntansi di sekolah menengah kejuruan: Juni 2107 di Pendidikan Akuntansi FKIP.

Slavin, E. Robert. 2009. Cooperative Learning Teori, Riset dan Praktik. Bandung: Nusa Media.

Solihah, Ai. 2016. Pengaruh model pembelajaran Teams Games Tournament (TGT) terhadap hasil belajar matematika : Jurnal SAP Vol. 1 No. 1.

Soleh, Maulana Ibnu, Dadang Kurnia, dan Dede Tatang Sunarya. 2017. Penerapan Model Pembelajaran Kooperatif Tipe Teams Games Tournament (TGT) Pada Pembelajaran PIPS untuk Meningkatkan Hasil Belajar Siswa pada Materi Sumber Daya Alam dan Kegiatan Ekonomi. Jurnal Pena Ilmiah: Vol 2 No 1 Hal. 2101-2110.

Solihah, Ai. 2016. Pengaruh Model Pembelajaran Teams Games Tournament (TGT) terhadap Hasil Belajar Matematika. Jurnal SAP Vol. 1 No. 1 Hal. 45-53.

Sudjana. 2005. Metode Statistika. Bandung: Tarsito.

Syah, Muhibin. 2010. Psikologi Pendidikan dengan Pendekatan Baru. Edisi Revisi. Bandung: PT Remaja Rosdaka.

Sumardi. 2014. Model pembelajaran Teams Games Tournament untuk meningkatkan hasil belajar siswa SMK: Universitas Pendidikan Indonesia.

Yuna, Murpini, 2016. Pengaruh perubahan kurikulum 2013 terhadap perkembangan peserta didik, Universitas Swadaya Gunung Jati Cirebon. 